\title{
Hidden treasure lore in Estonian folk tradition
}

\section{Mare Kalda}

\begin{abstract}
The article focuses on treasure lore in Estonian folklore. It is based on the collection of 2000 folkloric texts, kept in the Estonian Folklore Archives and collected throughout the past 150 years. Stories present in anthologies, print media and to some extent also digital media were included in the analysis. The article attempts to point at the differences between these texts on the one hand and everyday conversations about money on the other: in the case of the former the stress is on the symbolic aspect of imagery and attitudes, as well as on values and choices of the community.

Estonian treasure lore, carrying essential similarities with folklore from neighbouring regions, addresses the fantasies of becoming rich, nurtured by human hopes and desires, but at the same time the stories also incorporate the factual, biographical and other details from the physical reality. Treasure stories are characterised by emphasised locality and temporality as well as money-related and other more general folk beliefs.

The article also examines questions regarding the functions of treasure stories. Story-telling is motivated by its entertainment value, the feeling of possessing valuable information, and a wish to avoid the unwanted actions of other community members.
\end{abstract}

Keywords: hidden treasure, money in folklore, functions of legends

The modern society constantly talks and writes about money. While in everyday conversations we discuss its abundance or the lack of it and the means of obtaining and spending money, studies from the field of economics concentrate on the detailed depiction of financial problems in their full complexity. Financial economics is an independent discipline taught in the departments of economics in universities, analysed in research institutions, published in encyclopaedias (e.g. Wood 1998; Lee \& Lee 2006; Fabozzi 2008) and historical overviews (Davies 1994; Williams \& Cribb \& Errington 1997; Ferguson 2008; concerning Estonia, see Leimus et al. 2006). Topically oriented institutionalised 
as well as non-institutionalised discourses are surrounded by and immersed in folklore as popular interpretations of money-related issues expressed in different folklore genres.

The current article discusses treasure lore - one discourse among the other possible discourses about money $^{1}$, one way of talking about money in a society - and outlines the peculiarities and functions of treasure tales on the basis of Estonian folk tradition. An overview of the history of money, the etymologies of central notions in the field as well as an account of the archaeological studies of hoards remain outside the scope of the current study. In a similar vein, the actual socio-economic situation, motivating the creation and dissemination of treasure lore, will be mentioned only in passing. In order to characterise the folkloric treasure discourse I am going to first define the horizons of treasure lore and determine how folk tales, compared to everyday conversations about money, reveal different attitudes and experiences towards valuables. The second half of the article will discuss the functions of treasure stories in folklore.

\section{The topic of money in everyday conversation and folk tales}

Treasure lore involves the traditional and contextualised beliefs of actual and/ or symbolic possibilities of improving one's economic status - usually in the form of short narratives. It reflects both in its oral and written forms the relevant experiences and hopes of people, which are a sign of individual desire for wealth against the backdrop of common values of the community. At the same time, traditional treasure discourse is a conceptual abstraction, an excerpt from the large body of folklore, which exchanges material with other layers of the tradition and is also engaged in a dialogue with other cultural phenomena and practices. Treasure stories inspire novel writers and film producers. They can also serve as an additional research source for archaeologists.

Estonian treasure stories share a considerable number of common features with other nations. Especially Finnish, Swedish, German, Latvian and Russian folk stories became known in Estonia through actual cultural contact (for a closer study on that, see Kalda 2011: 15-26 and the references within). Treasure stories dealing with witchcraft have come from German folklore, whereas motifs about treasure light are an influence of the Scandinavian tradition. It becomes clear in a closer analysis that striking similarities are also present with regard to geographically more faraway regions that have had no

1 I am using here the term discourse in its wider sense, denoting active verbal communication as defined by Ruth Finnegan in her characterisation of research practices of oral traditions and verbal arts, see Finnegan 1992: 13 and the authors she refers to. 
direct contact with Estonian story-telling tradition. This calls for an analysis of the psychological motivation behind treasure lore. In addition to this, also actual treasure finds have inspired similar expressions of experience. Estonian treasure lore is typically bounded in time and space, localising the stories and making them unique.

The archived treasure stories that are studied in the present article date from the last decades of the $19^{\text {th }}$ century up to the beginning of the $21^{\text {st }}$ century. Within this time period, we can see the development of modern economic and monetary trade culture. Increasingly, it became quite usual to talk about the amount and role of money in daily life, its sufficiency or insufficiency, the structure of costs, but also to discuss the news or communal money problems in a wider sense. The linguist Kanni Labi (2011) has discussed the presence and meanings of the notion of money in the $19^{\text {th }}$ century and present day language, which has lead her to conclude that language practices point at changes that have taken place in the socio-economic status of people. She maintains that dictionaries from different times indicate how people obtain money and what they decide to do with it. She also claims that attitudes about money have nevertheless remained the same. From the point of view of contemporary language use, we should note that Estonian communication rules do not mark talking about money as impolite. The applied linguist Hille Pajupuu has studied communication styles in the Estonian language, and concluded that small talk occupies only the second place in everyday conversations, giving way to more in-depth conversations, including those about politics, health and money - topics which in many other cultures fall outside the scope of polite conversation (Pajupuu 1997). In oral and written communication, the concept of money is expressed in its language-specific common meaning as defined in the Dictionary of Standard Estonian: it is seen as a means of payment in the form of coins and banknotes, and secondly as denoting a pecuniary sum, capital, or assets (see EKKS, headword raha).

The functional meanings of the term refer to money as a means of payment and as a resource to be used. These meanings are sometimes inclined to stay in the background in traditional treasure tales. In addition to talking about ownership, salaries and prices, people seem to have a need to discuss the events and concepts related to money in a way that highlights its symbolic dimension, i.e. focusing on moral attitudes and values. In a sense, treasure lore diverges from everyday discourse, as well as from discussions about financial matters. ${ }^{2}$

${ }^{2}$ Debora Kapchan, in her treatment of the main feature of expressive culture, notes that a folkloric unit's performance is set apart from the flow of everyday practice (Kapchan 2003: 131-132). Compared with artistic performances, treasure tales are less distinctive in their narrating situations, which is characteristic of legend narrations. According to Paul Smith, the narration of a contemporary legend stems from normal conversation rather than comes in response to a request to tell a tale (Smith 1999). 
These topics may be addressed in treasure lore, where stories define the good and the evil and elaborate on what is permitted or disapproved of. This is all present within the popular treasure discourse, and it is to some extent obvious already on the conceptual level where we can find terms like rahaauk ('money pit'), rahapada ('pot of money'), rahatuli ('treasure light'; for more on terms found in the $19^{\text {th }}$ century dictionaries, see Labi 2011: 349), as well as varanduse valvur ('treasure guardian'), aardehaldjas ('money fairy'). Notions about mythology, recorded in the $19^{\text {th }}$ (and early $20^{\text {th }}$ ) century dictionaries, are still present in treasure stories created in the $20^{\text {th }}$ century. Their re-contextualisation is still strong in the electronic media where folkloric texts are disseminated and retold from a personalised point of view.

The way treasure is put into use is the central theme in stories about finds claimed to be real, as they tell us about how for example finding a money pot made it possible to buy new farm equipment and livestock or educate children. Such stories usually include an episode which points to the need to exchange the outdated, valueless coins for valid currency. Other stories, on the contrary, do not assign any economic value to the find: in those, coins lacking practical worth are sometimes given to children as toys. In addition to these opposite evaluations, the third and more neutral solution is such where the valuables are turned over to the museum. In that case, the historical and antique value is emphasised. This indicates a selective assimilation of the elements and rhetoric of archaeological (i.e. scientific-institutional) discourse into tradition. All the above mentioned solutions to the stories are apparent in those tale types which stand out from the corpus by the fact that the events lead to actually finding the treasure. A happy, i.e. successful ending is not so frequent in treasure stories, the ratio between finding and not finding the treasure being 1:3, though this may vary in different publications. Anthologies which comprise experience stories about real stray finds show a ratio of 3:5; whereas a collection of stories that does not recount archaeological treasure finds display a ration of only $3: 10 .^{3}$ From the point of view of story types, the texts which end in success stand out. A fifth of these tell a story of economic gain, an equal amount of stories end with taking the find to the museum, and all the rest leave the final fate (as well as the worth) of the treasure find open.

A fair share of treasure legends concern fatal choices, the complex conditions of acquiring the treasure, and dangerous situations that are evoked by trying to dig up the treasure. Thus, the basic idea lies outside the potential uses of

3 John Lindow characterises Swedish treasure lore from the same pespective, mentioning the ratio 1:2 (different in Lund region, where the ratio is 1:4). He also refers to treasure stories from Texas, USA, where according to Patrick Mullen 3 tales out of 11 report of success (Lindow 1982: 264, 271). 
the treasure. There are supernatural sanctions which are frightful enough to impede or completely prohibit people from obtaining the treasure. Even in stories that end with success, luck can be temporary and the obtained treasure may eventually be lost. Contrary to the stories where the treasure is claimed to have played a role in helping the household reach prosperity, some legends give accounts of bad luck and desolation that follows the treasure finders for several generations.

\section{Facts and fantasies revealed through genres of treasure lore}

Legends, followed by personal experience narratives, jokes, folk beliefs, exempla and some types of fairy tales, are the main folklore genres ${ }^{4}$ in Estonia, the function of which is to express the experiences, perceptions and popular explanations of treasure-related events. Therefore, the uniting principle is thematic similarity, but not their belonging to the same genre. In treasure lore, different genres emphasise different aspects of the same topic: in the most general framework, the rhetoric, word usage, meaning and attitude towards the reality of different genres contribute to one and the same discourse. The imaginary and the empirical become blended in the texts: fictional elements incorporate facts (and vice versa: facts as if stick to fictional motifs), but the two categories can also be kept apart on purpose. Treasure tales and jokes convey fantasy motifs, impossible situations and plot twists, increasing thereby the fictive nature of folkloric discourse (cf. Klein 2006: 19). An example of such narrative would be the story about the treasure hunters who poison each other, hoping to gain the sole ownership of the money pot (tale type ATU 7635), as well as the story of the nobleman who disguises himself in an animal skin to force a lower-status treasure finder to give up his loot, but who later can no longer get out of his disguise (ATU 831). Another internationally spread humorous tale known in Estonia is "The Talkative Wife and the Discovered Treasure" (ATU 1381). In this example, the husband tries to discredit his wife so that she would not imprudently tell about the treasure discovered by accident.

${ }^{4}$ From the point of view of folklore genre theory, it is important to emphasise that the genres satisfy different needs, carry different symbolic meanings, and each genre has its own rhetorical features, vocabulary, and a disposition towards the reality (BenAmos 1976: 39).

5 International folk tale index, abbreviated as ATU (from the names of its original compilers and further developers A. Aarne, S. Thompson and H.-J. Uther) serves as a manual for folk narrative research in which tale types are registered and annotated. 
Nevertheless, fantasy images are also found in legends which claim to impart the truth ${ }^{6}$, or as Donald Ward (1991: 301) noted, are told as if they were factual. Several fantasy motifs are employed in metamorphosis legends, including the tales about seeing a treasure light. In these stories, also known in Estonia, people sitting around a mysterious fire lit a person's pipe, or he is given glowing coals in a bag (or hem, apron, or pocket); later it appears that the pieces of coal have turned into gold and silver coins. In other stories, the reverse transformation takes place: pieces of what was believed to be money turn into something worthless like tree leaves or thorns. Although the stories contain elements of unrealistic metamorphoses, they are not necessarily fairy tales. ${ }^{7}$ An imaginary idea is placed into the everyday environment of the tradition bearers. The focus is not so much on the factual or real occurrence of the event but on the possibility of its occurrence. Ulf Palmenfelt, who has studied the metamorphosis legends in Gotland, Sweden, states that these tales reveal different degrees of fictitiousness, consisting at times of realistic, but at other times unrealistic narrative elements. He proposes to interpret these legends not as examples of popular beliefs but as "a verbal game of imagination" (Palmenfelt 2007: 15-18).

\section{Treasure tales as belief legends: towards a psychological explanation}

A challenge for understanding and interpreting folklore is offered by mythological legends which depict the complex conditions of unearthing hidden treasure as well as the description of right actions to acquire the fortune. For example, the treasure cannot be obtained unless one casts a spell or follows some other

6 The truthfulness and/or credibility of legends are still a relevant problem in folk narrative research. Premises according to which a legend is presented as a true story have been abandoned. Linda Dégh considers the main characteristics of a legend to be the constant reformulation of its truth and credibility (Dégh \& Vázsony 1971). What is depicted in the legend seems to need constant re-affirmation of truthfulness, or negation thereof. Emphasising the multifaceted nature of the truthfulness of legends is relevant, since this encompasses all the possible attitudes towards the stories, both from the point of view of the believers as well as the sceptics. In the case of every particular story, a diachronic view needs to be considered as well. Certain topics, however, change in time, so that there is no one left in the community to believe the truthfulness of a story. This does not mean the topic is bound to oblivion. For example, after being published in legend anthologies, such tales become re-classified as cultural texts that offer reading material and, using the reframed rhetoric of truth, carry a potential to be retold again.

7 The exception is the tale type "The Poor Brother's Treasure" (ATU 834), wherein a dead animal (or a pot of dung) changes into money. Several characteristics, including the high level of fictionality, indicate its compatibility with the fairy tale genre. 
required steps, agrees to share the treasure with others, or performs special magic. According to legends, one must avoid misusing the name of God as well as calling the devil while pursuing the treasure. It is absolutely forbidden to break the silence under certain conditions, or strongly recommended not to be frightened by the treasure guardian. A great number of legends start with someone dreaming about unearthing a treasure and thus being given information about where the money pit is supposed to be. Several stories focus on the sacrifice that is needed to get the treasure (an animal, the blood of seven brothers, a sheep with lambs, the first person whom one sees when he/she reaches home) and give directions about the special manipulations necessary for obtaining the treasure (ploughing with a rooster and harrowing with a hen; ploughing naked or using a skinned animal; having a three-legged goat dancing at the treasure chest; boiling a black cat in order to get a particular bone that could help to surface the money pot from under the earth). All the events listed above can be linked to the image of supernatural punishment that the finder is subject to after trying to get the treasure which was obviously not meant for her/him. The wrong-doer is threatened with loss of sight, hearing problems, long-term illness, or just bad luck. Sometimes the cursed treasure makes the whole family suffer from diseases or accidents.

We are dealing with more or less elaborated migratory legends that circulate internationally and which are characterised by a high degree of adaptability into local settings: they are told as having happened in a real place and time, and they communicate about the events experienced by real people.

What has to be kept in mind is that on some occasions, belief legends have the power to maintain folk beliefs among tradition bearers. Treasure lore incorporates locally contextualised mythological imagery which provides a way to negotiate what might be acceptable or inappropriate for owners of valuables in general, and what forces seem to regulate treasure seeking in particular. On the other hand, regarding narrative elements as reflections of living folk belief can be misleading as some episodes in legends are told primarily because of their narrative interest, adding the details to the plot in order to make it more funny or exciting. Already in the 1960s, Lauri Honko, developing a theory of folklore, employed the category of entertainment legends to grasp the essence of such stories (see Honko 1964: 13). Accordingly, we can expect that treasure tales performed or displayed for entertainment purposes do not express the community's actual, inviolable instructions. ${ }^{8}$

Psychological factors that legends openly reveal or allude to make the understanding of narratives even more complicated. Archetypal images derived

8 On the relationships between legends and folk beliefs therein, see Christiansen 1958; Mullen 1971; Honko 1964; Tangherlini 1990; Koski 2008; esp. in regard of the context of contemporary legends Dégh 2001; Ellis 2003. 
from the collective unconscious (cf. Jung 1976) intrude into the conscious mind and consequently occur in tales, including their legends of hidden treasure.

Rather than painstakingly searching for the origin of particular beliefs, it might be sometimes more useful to describe the universal human dispositions that enter the consciousness and get to be articulated in stories which, when retold, stimulate the tellers' and listeners' imagination. The symbolic events depicted in treasure tales, such as turning a living creature into money after it is touched or beaten by a man, or transformation of useless matter into gold and vice versa, or replaceability of the beings and objects involved in the story, do have connections with the unconscious background. Legend episodes that depict unearthing the hidden treasure convey the desire to acquire wealth. This constitutes the underlying desire which is accompanied by the feelings of hope, uncertainty, doubt and anxiety. In this sense, treasure tales demonstrate the path leading from unconsciousness to consciousness: desire and excitement, together with premature feelings of getting lucky at one hand, and doubt or fear of the consequences on the other hand, need to be articulated and represented in multiple versions for channelling and organising the drives and emotions emerging from the subconscious mind. Through telling tales, the narrated reality is actualised in order to help us cope with situations concerning obtaining and losing valuable objects (treasure).

In addition to treasure stories in the folklore from old times, there are events and experiences that need to be newly verbalised in narratives. At the same time, they stay connected with both the contents of the collective unconscious and elements of traditional treasure lore. Consequently, there is a connection between the culture-bound nature of the narrative episodes and motifs used in treasure legends, and archetypal rootedness of symbols and imaginations (see also Röhrich 2008). In research practices this is manifested through the interpretation of stories and images either as being acquired culturally, i.e. through listening to the tales and learning them, or being explained by emphasising the psychological origin of the stories. ${ }^{9}$

It is quite common for treasure legends to include particular dreams about the treasure. People often claim having had a dream that informed them about the hoard's location as well as the conditions that go with it. Following the

9 From the perspective of analytical psychology, the idea of searching for something valuable can be seen as the process of individuation, which is a part of the process of establishing the Self. Hidden treasure symbolises the missing part of the totality of the psyche, the achievement of which proves to be a challenging task. For example, Emma Jung and Marie-Louize von Franz interpret the Holy Grail as a symbol of the Self because of its identification as a treasure which is hard to attain (Jung \& von Franz 1971: 155-156). Gotthilf Isler (1989: 57) discusses money in the shape of a woman as the feminine principle waiting for deliverance. The characters that counteract humans could be understood as The Shadow, the opposite of the ego image. 
approach according to which expressive phenomena spread across cultures, treasure dreams should be understood as culture-bound texts seeking expression in narrative form: both the experience and its verbalisation are explained as being conditioned by the culture. At the same time, analytical psychology categorises such complexes above all as mental events or spiritual reality (Jung 2005: 43) that not necessarily rule out the cultural influences. Especially first person treasure dream narratives are characterised by a high degree of involvement. However, dream-episodes are also present in legends where the recounted events are supposed to happen to another person (not the narrator), thus introducing a distance between the narrator and the hero of the story. In either case, the subjective reference to one's dream and elements of traditional lore are brought into connection to constitute a meaningful whole. Thus the subjective event and the more or less commonly known treasure tale intertwine as two fields of meaning.

The common knowledge that hidden treasure could be only obtained under certain conditions has given birth to several narrative versions serving to explain why the treasure cannot be found and why one's financial situation has still not become better. The would-be finder of the treasure faces a challenge because of his/her lack of courage, skills or means to uncover the fortune. Through illustrative cases, narratives enable to exemplify the failure which has happened to someone else, and which therefore can offer comfort to those who perceive their own resources as insufficient. The legend character as if realises his/her object of desire, and is, literally speaking, about to touch the treasure or hear the clinking coins, but the money pot still remains out of reach. We can see the inner ambiguity, even the controversiality of treasure lore: in addition to stories about unfound treasure, there are, however, stories about how someone has succeeded in obtaining it. It is so because the tellers and listeners are willing to symbolically identify themselves with legend characters who are lucky enough to find a fortune.

It should be pointed out that treasure lore concerns and reflects the social relations and norms of everyday behaviour. This is characteristic of all traditional legends. At the same time, they are a channel for subconscious desires. Typically of the traditional treasure discourse, these stories combine the archetypal desire to own possessions and the social sanctions related to the possibility of finding a treasure as well as to its actual acquisition. Furthermore, treasure tales demonstrate what is socially acceptable and how to seek for a fortune. The hope to improve one's financial situation is overshadowed by the understanding that success could be achieved, but at a price. The legend corpus includes a whole narrative arsenal to account for situations where social norms, institutions, and authorities suppress the desire to own something hidden or 
lost - the stories involve a range of different episodes which force the main character to avoid treasure hunts or abandon the treasure after unsuccessful trials. The same function is served by the supernatural sanctions exercised by the mythological treasure owner or guardian. It remains unclear to what extent the supernatural counterforce serves as a maintainer of social norms or if this force can be interpreted as a self-projection of a human (the inner opponent) who sometimes tries to restrict the performance of the Self.

\section{"Being in the know" and the other functions of treasure stories}

The meanings and functions of treasure stories are also relevant issues in this context. The main question is whether treasure tales carry the same functions as folklore in general. Since people used to discuss the hidden treasures mostly in the form of legends, would it thus make sense to observe the shared functions of the whole genre and then try to specify the particular features of treasure lore? Furthermore, it is relevant to know whether treasure discourse displays a unity in both its content (thematic aspect) and form (genre aspect). For example, it is possible to see a resemblance between a given treasure legend and an anecdote told about the treasure hunt because of the shared topic, but on the other hand, there is also a shared function, i.e. to warn somebody of something. This relates the two narratives to each other even if their topics do not coincide. Robert Georges (1969: 319) considers the functions of folk stories to be essential for understanding their meaning in storytelling events. Studying the meaning of stories is often seen as complicated and sometimes impossible due to the unconscious nature of human fantasies (Dundes 1980: 36). The analysis of the functions of treasure stories could make it possible to capture the meaning of the legends.

The roles of folklore have been analysed in an early article by William Bascom (1954), who offers an explanation for the ambivalence that exists in treasure lore. ${ }^{10}$ Bascom insists that "folklore serves as a mirror of culture and incorporates the expression of beliefs and attitudes among other elements involved in it. But at the same time characters in tales do things which are prohibited in daily life" (ibid.: 337-338). Thus, treasure tales depict real events and beliefs related to hidden treasures, but also the unreal (impossible or unbearable) ones. The unique nature of treasure lore creates a feeling of indeterminacy: it is not clear which events told in legends are real and which are unreal. Besides, without

10 The ambivalent attitude towards the topic of money in folklore has also been pointed out by other researchers, e.g. Bogdanov 1999: 85; Iżykowska 2013: 246, this volume). 
renouncing the archetypal drives, one could say that any cultural expression reflects the society in which it exists.

Bascom listed four basic functions of folklore, and exemplified how on the one hand folklore maintains the stability of culture, while on the other it offers a medium for talking about what does not exist or should not exist. According to Bascom (1954: 345-346, 349), folklore lets people escape from the repressions imposed upon them by the society, but at the same time offers means of applying social pressure and exercising social control.

Studies of the Estonian treasure lore (Kalda 2011: 18-21, 73-93, 101-107) indicate how similar situations, hopes and behaviours are treated differently in different tales. In some stories, a hoard found while ploughing can be picked up or acquired after it is marked with a personal item, whereas in other stories the same situations and behaviours lead to a different ending: money, once dug up, sinks back into the depths; coins that seemed valuable at first sight change into decayed leaves; some creature scares away the finder; or his/her relatives fall seriously ill or have accidents which are supposedly caused by their find, etc. Thus, both kinds of story plots are present in folklore: those dealing with lucky finds as well as those in which the rhetoric largely expresses doubt in the possibility of obtaining treasures.

Sandy Hobbs (1987) reaches an interesting conclusion concerning the functions of folk stories drawn from the study of contemporary legends. He has studied the frequency of six functions in a number of legend anthologies. According to his notes, two primary functions surpassed others: first of all, the justification of anxiety that people otherwise might be ashamed of, and secondly, poetic justice, punishing a wrongdoer. The first category gives an excellent explanation to a set of treasure legends where the main character in the story does not dare to unearth the hoard although he/she seems to have information about its location. Alternatively, the person stops the search because of the paralysing fear felt at meeting a supernatural being or other dangers while seeking or reaching for the treasure. Narratives often incorporate descriptions of fear as well as difficulties of different kind. These descriptions are the projections of inner psychological processes which contribute to the external set of excuses, and serve the purpose of justifying (or reasoning about) the integrity of the said treasure. Folk narrative researchers share the opinion that the legend genre discusses important issues of life, including the fear of poverty and loss (Dégh 1991: 13; Röhrich \& Uther 2004: 1021). Thus, depending on the circumstances, one function of legends is to either reveal or conceal the emotion in question. Interestingly enough, poetic justice, which Hobbs sees as the central function in urban legends, is manifested rather in the older layer of traditional treasure tales. In contrast to whole treasure tale corpus, these 
stories put a special emphasis on the gap between the rich and the poor as well as the powerful and the powerless. Several plots concentrate on the failure of already well-off, socially high-standing persons who were about to gain even bigger wealth at the expense of a lower-standing and poorer person. One story tells, for instance, how the local landlord had once arranged the excavations of the money pit with the help of local peasants, who helped him, and although having promised to give a part of the treasure to the peasants and for charity, he changes his mind after the treasure chest becomes visible. Poetic justice is even more explicit in the above-mentioned international tale type ATU 831 "Clergyman in Disguise as the Devil" (previously entitled as "The Dishonest Priest") and ATU 834 "The Poor Brother's Treasure".

The function formulated as "being in the know", which was not in the foreground of the contemporary material studied by Hobbs, is nevertheless very characteristic of all treasure lore. It is common to show through treasure tales how knowing something confidential or possessing some special knowledge makes a difference, in particular concerning folklore related to specific locations or settings. To the community, it denotes first of all common knowledge expressed through symbols and details which construct the local identity. In narrating situations, location-based knowledge is maintained and revitalised.

In some cases, the seemingly confidential local folklore reaches a wider audience. This happens when the stories are published in folk tale anthologies or disseminated through other channels of communication. As a result, more people become included in the circle of the initiated, and anyone interested in the place and its history ${ }^{11}$ will have access to information that previously was spread only within a small group of tradition bearers. Former secret knowledge becomes public and can be used for sheer entertainment; tradition-based information becomes oriented towards outsiders and is re-contextualised in the form of colourful stories about local points of interest. This can happen, for instance, in tourism industry.

Indeed, the Internet provides numerous hidden treasure legends. For example, various nature trails all over Estonia retell stories of hidden treasure in order to attract possible visitors. In Virumaa county in northern Estonia, people who hike along the lake can visit places where, according to legends, the treasure of the Swedish king was drowned, and see excavation holes made by treasure seekers (see Nature Trail 2012). In Western Estonia, the former Nurtu estate's historical overview is interwoven with a locally well-known story about the treasure in Nurtu river (see Velise 2012). It is said that to obtain it, one must harness a pair of black oxen, and half of the hoard must be shared

\footnotetext{
${ }^{11}$ Folklore is part of a region's intimate, grass-root level history; see Ryden 1993: 62-66.
} 
with poor people. In a sense, the being-in-the-know function of treasure lore is performed by professional folklorists, and is visible in publishing strategies (e.g. Rehepapp 2005).

Legends about treasure hunters from outside a local community reveal the confidentiality aspect of treasure lore from a somewhat different angle, emphasising the difference between insider and outsider knowledge. The main storyline of these tales displays the following pattern: a treasure is known to be hidden somewhere, as people tell of having dreamt about it or seen a treasure light burning. The place may be an ancient burial ground which causes apparitions and other unusual visions. Subsequently, foreign-speaking strangers appear, equipped with documents and maps, and ask to be directed to the particular spot in the local landscape. After a while, the strangers leave, and leave behind an empty hole / treasure chest / pot.

Such narratives deal with the question of control over information, i.e. the situation where the knowledge regarded as local turns out to be known even more precisely outside the community. These stories show who is interested in the treasure and why. There is a variability to how the probable location of the treasure is found out. A set of narratives refer to treasure maps held in Swedish archives, required in order to find the hoard. ${ }^{12}$ Although the necessary information is claimed to be far off and hard to access, people still go searching for the treasure. In another plotline, the Swedish maps are mentioned as the main source of information, but the local people either remain passive bystanders or, sometimes, happen to be in a witnessing role. As a result, the treasure is removed by the strangers. A third scenario includes a contact between the outsiders and the villagers: the visitors hire local help, ask for accommodation and even give clues about their intentions. Nevertheless, the very act of excavation still remains a secret that enables reinterpretation.

Legends as worlds of narrated possibilities express the hope and wish to obtain a fortune. Since that rarely happens in real life, tales are needed to express the feeling of being left empty-handed. This is why so various plots reveal where the supposed treasure exists, but stress its inaccessibility due to an external (or internal) force that will disrupt the attempt to obtain it.

\footnotetext{
${ }^{12}$ In order to understand the story, it is important to note that in the $17^{\text {th }}$ century, Estonia was under the Swedish rule (see Laar 2006: 62-72; Estonica 2012). "The Swedish time" has explicitly influenced the temporalisation of events depicted in local historical tradition related to hidden treasures. Legends say that the Swedes buried their treasures everywhere in Estonia before and during the Great Northern War. The historical background to the popular idea that the treasure maps are held in closed archives in Sweden has been shaped by the actual cadastral mapping for administrative and judicial purpose carried out during the $17^{\text {th }}$ century also in Swedish Baltic provinces (Kain \& Baigent 1992: 68-75; Must 1993).
} 


\section{Conclusion}

Connecting the functions and actuality of legends, we can conclude that Estonian traditional treasure tales have met the needs of the traditional community by retaining and selectively mediating specific traditional information focused on a particular topic. Treasure stories have helped to establish justice, showing the poor getting an access to wealth: these include the few stories of earned luck and good fortune. The numerous stories of how the treasure is not discovered stand in support of the realistic point of view, because in real life, quick financial success is hardly ever possible.

In treasure lore, the fears and hopes associated with acquiring and possessing valuable resources are verbalised, as stories stylistically range from nearly factual descriptions to collections of fantasy episodes. The human propensity to treat the problems related to property affects the stories in a more superficial way, contrary to how it is expressed in everyday discussions. Popular approach entails the symbolic dimension and moral attitudes, categories of the good and the evil, links to local history, and references to real persons and places in traditional treasure discourse.

Consequently, treasure lore as a part of Estonian folk tradition serves as means for negotiating and maintaining beliefs about values. The choice of categories and fantasies reflected in treasure tales as well as the connections and replacements found in the episodes thereof also shed some light on the mental processes of treasure-related imagery and its actualisation by the unconscious mind. 


\section{References}

ATU $=$ Uther, Hans-Jörg 2004. The types of international folktales. A classification and bibliography based on the system of Antti Aarne and Stith Thompson. FF Communications, Nos. 284, 285, 286. Helsinki: Suomalainen Tiedeakatemia.

Bascom, William 1954. Four functions of folklore. Journal of American Folklore, Vol. 67, No. 266, pp. 333-349.

Ben-Amos, Dan 1976. The concepts of genre in folklore. Folk narrative research. Some papers presented at the VI Congress of the International Society for Folk Narrative Research. Studia Fennica 20. Helsinki: Suomalaisen Kirjallisuuden Seura, pp. 30-43.

Bogdanov, Konstantin 1995 = Богданов Константин Анатольевич. Деньги в фбольклоре. Санкт Петербург: Белл.

Christiansen, Reidar Th. 1958. The migratory legends. A proposed list of types with a systematic catalogue of the Norwegian variants. FF Communications 175. Helsinki: Suomalainen Tiedeakatemia.

Davies, Glyn 1994. A history of money: From ancient times to the present day. Cardiff: University of Wales.

Dégh, Linda \& Vázsonyi, Andrew 1971. Legend and belief. Genre 4, pp. 281-304.

Dégh, Linda 1991. What is the legend after all? Contemporary Legend, Vol. 1, pp. 11-38.

Dégh, Linda 2001. Legend and belief: Dialectics of a folklore genre. Bloomington: Indiana University Press.

Dundes, Alan 1980. Interpreting folklore. Bloomington: Indiana University Press.

EKKS = Eesti keele seletav sõnaraamat. [Explanatory dictionary of standard Estonian.] http://www.eki.ee/dict/ekss/index.cgi?.

Ellis, Bill 2003. Aliens, ghosts, and cults. Legends we live. Jackson: University Press of Mississippi.

Estonica 2012 = Estonia under Swedish rule. Encyclopedia about Estonia by the Estonian Institute.http://www.estonica.org/en/History/1558-1710_Estonia_under_Swedish_rule/, last accessed on 2 April 2012.

Fabozzi, Frank J. 2008. Handbook of finance, Vols. 1-3. Hoboken: John Wiley and Sons, Ltd.

Ferguson, Niall 2008. The ascent of money: A financial history of the world. London, etc.: Allen Lane.

Finnegan, Ruth 1992. Oral traditions and the verbal arts: A guide to research practices. ASA Research Methods in Social Anthropology. London \& New York: Routledge. 
Georges, Robert 1969. Toward an understanding of storytelling events. Journal of American Folklore 82, pp. 313-328.

Hobbs, Sandy 1987. The social psychology of a good story. Perspectives on Contemporary Legend II. CECTAL Conference Papers Series 5. Sheffield: Sheffield Academic Press, pp. 133-148.

Honko, Lauri 1964. Memorates and the study of folk beliefs. Journal of the Folklore Institute 1, 1/2, pp. 5-19.

Isler, Gotthilf 1989. Die Schatzjungfrau - "nur" eine arme Seele? Zum psychologischen Verständnis einiger Erlösungssagen. In: L. Petzoldt \& S. de Rachewiltz (eds.) Der Dämon und sein Bild. Berichte und Referate des dritten und vierten Symposions zur Volkserzählung Brunnenburg/Südtirol 1986/87. Beiträge zur Europäischen Ethnologie und Folklore Reihe B: Tagungsberichte und Materialien 2. Frankfurt am Main: Peter Lang, pp. 43-64.

Iżykowska, Małgorzata 2012. Money as an object of desire in Silesian folklore. In: L. Laineste \& D. Brzozowska \& W. Chłopicki (eds.) Estonia and Poland. Creativity and tradition in cultural communication, Vol. 2: Perspectives on national and regional identity. Tartu: ELM Scholarly Press, pp. 231-248.

Jung, Carl Gustav 1976. Die Archetypen und das kollektive Unbewußte. Gesammelte Werke. Neunter Band, Erster Halbband. Olten-Freiburg: Walter.

Jung, Carl Gustav \& von Franz, Marie-Louise \& Henderson, Joseph \& Jacobi, Jolande \& Jaffé, Aniela 2005. Inimene ja tema sümbolid. [Man and his symbols.] Tallinn: Eesti C. G. Jungi Analüütilise Psühholoogia Selts.

Jung, Emma \& von Franz, Marie-Louize 1971. The Grail legend. London: Hodder \& Stoughton.

Kain, Roger J. P. \& Baigent, Elizabeth 1992. The cadastral map in the service of the state: A history of properly mapping. Chicago: University of Chicago Press.

Kalda, Mare 2011. Hidden treasures in Estonian tale tradition: From deeds to folk legends. Dissertationes folkloristicae Universitatis Tartuensis 15. Tartu: University of Tartu Press.

Kapchan, Deborah 2003. Performance. In: B. Feintuch (ed.) Eight words for the study of expressive culture. Urbana \& Chicago: University of Illinois Press, pp. 121-145.

Klein, Barbro 2006. Introduction. Telling, doing, experiencing. Folkloristic perspectives on narrative analysis. Narrating, Doing, Experiencing. Nordic Folkloristic Perspectives. Studia Fennica. Folkloristica 16. Helsinki: Finnish Literature Society, pp. 6-28.

Koski, Kaarina 2008. Conceptual analysis and variation in belief tradition: A case of death-related beings. Folklore: Electronic Journal of Folklore 38, pp. 46-66. www.folklore. ee/folklore/vol38/koski.pdf, last accessed on 23 January 2013.

Laar, Mart 2006. Estonia's way. Tallinn: Pegasus. 
Labi, Kanni 2011. Krabisev ja kõlisev eestikeelses aegruumis. [Money in the space-time of the Estonian language.] Keel ja Kirjandus 5, pp. 343-359.

Lee, Cheng-Few \& Lee, Alice C. 2006. The encyclopedia of finance. New York: Springer Science \& Business Media.

Leimus, Ivar \& Erelt, Pekka \& Laar, Mart \& Sakk, Ivar 2006. Eestlase raha läbi aegade. [Money of the Estonians throughout the ages.] Tallinn: Eesti Ekspressi Kirjastus.

Lindow, John 1982. Swedish legends of buried treasure. Journal of American Folklore 95 (377), pp. 257-279.

Mullen, Patrick 1971. The relationship of legend and folk belief. Journal of American Folklore 84 (334), pp. 406-413.

Must, Aadu 1993. The great Swedish cadaster in the service of the Russian empire. Die Schwedische Ostseeprovinzen Estland und Livland im 16.-18. Jahrhundert. Acta Universitatis Stockholmiensis. Studia Baltica Stockholmiensia 11. Uppsala, pp. 257-266.

Nature Trail 2012 = Äntu-Nõmme nature trail. Lääne-Virumaa, Väike-Maarja area. http://www.v-maarja.ee/?part=html\&id=110\&lng=eng, last accessed on 2 April 2012.

Pajupuu, Hille 1997. Eestlased ja soomlased - probleemitud suhtlejad. [Estonians and Finns - problem-free communicators.] Keel ja Kirjandus 8, pp. 547-550.

Palmenfelt, Ulf 2007. Some thoughts about form in metamorphosis legends. Indian Folklife. A Quarterly Newsletter from National Folklore Support Centre 25, pp. 14-19.

Rehepapp 2005 = Mare Kõiva \& Mare Kalda et al. (eds.) Rehepapp. Database of folk Belief and Legends. http://www.folklore.ee/rehepapp/, last accessed on 2 April 2012.

Röhrich, Lutz 2008. The psychological approach: The interpretation and meaning of fairy tales: "And they are still living happily ever after". Anthropology, cultural history, and interpretation of fairy tales. Burlington: University of Vermont.

Röhrich, Lutz \& Uther, Hans-Jörg 2004. Sub verbo Sage. In: I. Köhler-Zülch \& U. Marzolph \& C. Shojaei Kawan \& H.-J. Uther (eds.) Enzyklopädie des Märchens: Handwörterbuch zur historischen und vergleichenden Erzählforschung 11. Berlin \& New York: Walter de Gruyter, pp. 1017-1049.

Ryden, Kent 1993. Mapping the invisible landscape: Folklore, writing, and the sense of place. American Land and Life Series. Iowa City: University of Iowa Press.

Smith, Paul 1999. Definitional characteristics of the contemporary legend. FOAF Tale News. Newsletter of the International Society for Contemporary Legend Research 44, pp. 5-7.

Tangherlini, Timothy 1990. "It happened not too far from here... ": A survey of legend theory and characterization. Western Folklore 49, pp. 371-390.

Velise 2012 = Sub verbo Mõisad: Nurme. Velise Kultuuri ja Hariduse Selts. http://www. velise.ee/m6isad_files/nurme.html, last accessed on 2 April 2012. 


\section{Mare Kalda}

Ward, Donald 1991. On the genre morphology of legendry: Belief story versus belief legend. Western Folklore 50 (3), pp. 296-303.

Williams, Jonathan \& Cribb, Joe \& Errington, Elizabeth 1997. Money: A history. London. Wood, Douglas 1998. The Blackwell encyclopedic dictionary of finance. Oxford: Blackwell. 